\title{
Nursing Staff Awareness Regarding Challenges for Applying Total Quality Management
}

\author{
Faten Abd Elhamed Mohamed ${ }^{1}$, Fatma Rushdy Mohamed ${ }^{2}$, \\ Safaa Mohamed Abd Elrahman ${ }^{3}$ \& Sanaa Mohamed Aref ${ }^{4}$.
}

1. Director of Contamination Control Department at Assuit University Hospital,

2. Professor of Nursing Administration - Faculty of Nursing Assuit University,

3. Professor of Nursing Administration - Faculty of Nursing Minia University,

4. Assistant Professor of Nursing Administration - Faculty of Nursing Minia University, Egypt.

Corresponding Author Email: afaten89@yahoo.com

\begin{abstract}
Background: Total Quality Management represents a modern management philosophy, established due to the development in all aspects of life in today's world. Aim: To assess nursing staff awareness regarding challenges for applying Total Quality Management at Assuit University Hospital. Research design: A descriptive study convenience sample design with a sample contains all nurses working in General Surgical, Special Surgical, General Medical, and Special Medical departments at Assiut University Hospital with a total number of $n=219$. Tools: Total Quality Management Challenges questionnaire is used. Results: Show that above one-third of them agree about all items of challenges for applying total quality management. Conclusion: No statistically significant differences between quality management challenges with personal and occupational characteristics of the studied nurses at Assuit University Hospital. Recommendations: Conduct an awareness sessions about total quality management between nurses at Assuit University Hospital; Conduct a total quality management training or program to all nurses at Assuit University Hospital, And the availability of quality assurance coordinator nurse in each department who works to implement quality policies in the departments and act as a link between the department and the Quality Committee.
\end{abstract}

Key words: Challenges, Nurses Awareness, Total Quality Management

\section{Introduction}

Healthcare organizations face some serious challenges, particularly concerning effectiveness, efficiency, and quality. Therefore, there is a pressing need for a new approach in managing healthcare organizations to become more cost-effective in the delivery of high-quality healthcare services (Mosadeghrad, $201 \varepsilon$ ).

Quality management constitutes an appropriate response to these challenges. It is a potential way to improve systems and procedures as effective as possible by using scientific methods to achieve an optimum outcome. Total quality management as a quality management strategy aims to enhance customer satisfaction and subsequently organizational performance by providing high-quality products and services through the participation and collaboration of all stakeholders, teamwork, customer-driven quality and continuously improving the performance of inputs and processes by applying quality management techniques and tools (Najm, Yousif \& Al-Ensour, 2017).

Nowadays, several hospitals and service managers try to look at the best ways and means to improve the administrative quality of their products. Many are wondering what successful leaders should do to improve their organizations to lead them to excellence among global organizations. Such questions reflect the aspirations of the vast majority of contemporary business organizations and highlight the importance of finding the most appropriate means to achieve this level (Hao \& Yazdanifard, 2015).

Advantages of implementing total quality management: Improving the organization's reputation faults and problems are identified quickly (the "zero defects"); Significant improvement in quality of products or services; Customer satisfaction increase, which leads to additional sales; A significant decrease of resources waste; Increased productivity because the staff uses the time more efficiently; Increasing the market share on the long term; The workforce is motivated by additional responsibilities, teamwork, and involvement in decision-making on total quality management; Lower costs; Focus on continuous improvement (Wamuyu, 2015).

Elewa \& Elkattan, (2017) conducted a survey for a hospital to identify the major obstacles to total quality management implementation in health care organization as; Organizational structure; Leadership style; Organizational culture; Professional autonomy; Lack of Consensus; Internal requirement domination; Efficiency-oriented; And manpower shortfall.

Aim of the study:

The aim of the current study is to assess nursing staff awareness regarding challenges for applying total quality management at Assuit University Hospital.

\section{Research question:}

What are the challenges that hinder the application of total quality management at Assuit University Hospital?

\section{Subjects and Method \\ Study Design:}

A descriptive research design was used to achieve the aim of the current study.

Sample:

A convenience sample of studied nursing staff at Assuit University Hospital. 
Setting:

The study was conducted in General Surgical, Special Surgical, General Medical, and Special Medical departments at Assuit University Hospital.

\section{Subjects:}

The present study included all head nurses and staff nurses who worked in the previous settings, which contains head nurses $(n o=17)$ and $(n o=202)$ staff nurses which were distributed as follows. General Surgical and Special Surgical departments number of head nurses $(n=8)$ and $(n o=80)$ number of staff nurses and General Medical and Special Medical departments number of head nurses $(n o=9)$ and $(n o=$ 122) number of staff nurses.

\section{Study tools:}

Self-administered questionnaire namely Total Quality Management Challenges Questionnaire. It includes two parts:

- $1^{\text {st }}$ part Personal Data; it was including information about head nurses and staff nurses. The data included items related to age, gender, unit, educational qualification, years of experience, and attended training courses.

- $2^{\text {nd }}$ part Total Quality Management Challenges questionnaire; this tool was developed by Korani, (2017). This tool was adopted and included (26 items) total quality management challenges. The researcher added one open question about the other challenges not mentioned in the questionnaire.

The scoring system of the study tool is 5 points Likert scale ranged from to Strongly Disagree (1), Disagree (2) Neutral(3), Agree (4) to Strongly Agree(5).

\section{Validity of the tool:}

Tool was tested for the face and content validity by a jury of (five) experts in the field of Nursing Administration and necessary modifications were done. The jury composed of one Professor from Faculty of Nursing, Ain-shams University; one Professor from Faculty of Nursing, Cairo University; and three Professors from Faculty of Nursing, Assuit University. Each of the expert panel was asked to examine the instruments for content coverage, clarity, wording, length, format and overall appearance.

\section{Reliability of the tool}

The internal consistency measured to identify the extent to which the items of the tool measure the same concept and correlate with each other by Cronbach's alpha test and it was proven test for each part according to the following formula:

$$
\begin{gathered}
\text { Reliability of } \\
\text { tool }
\end{gathered}=\frac{\text { No of agreement }}{\begin{array}{c}
\text { No of agreement }+ \text { No of } \\
\text { disagreement }
\end{array}} \times
$$

Reliability of the tool was performed to confirm consistency of the tool Total Quality Management Challenges Questionnaire witch found equal $\alpha$ o.849

\section{Operational Design}

The operational design for this study included three phases namely: Preparatory phase, Pilot study, and Data collection:

\section{Preparatory Phase:}

This phase took around three months from April to the end of Jun (2019). Reviewing the available related literatures and studies concerning the study topic, and an Arabic translation of the study tool was done.

\section{Pilot Study:}

A pilot study was conducted on $10 \%$ of head nurses $($ no $=2)$ and $10 \%$ of staff nurses $(n o=20)$ before beginning the field of data collection to obtain information which could improve the research plan and facilitate the execution of the study. The main purposes of the pilot study were to test the data collection tool regarding the phrasing, the order, and the need for adding or omitting questions or items that included in the tool, determine what kinds of difficulties could arise and how to deal with them and estimate the time required to complete the tool. It was taken about $20-25 \mathrm{~min}$ for filling the sheet.

\section{Data Collection:}

Official approvals to obtain data were introduced to administrative authorities; and approvals included a brief explanation of the objectives of the study. Arabic translation of the study tool was done by the researchers. Oral consent was obtained from all head nurses and staff nurses agreed to participate in the study. For the head nurses and staff nurses, the researchers interviewed them and provided a brief explanation about the purpose and the nature of the study to them. The researchers interviewed with head nurses and staff nurses in morning shift during the working days and waited with them during their working hours to fill it and it was collected after filling. The duration of data collection was lasted on three months from the beginning of September to the end of November (2019).

\section{Administrative design:}

A written initial approval was obtained from the Research Ethics Committee of the Faculty of Nursing, Minia University. Official letters were obtained from the director of the hospital and the nursing manager.

\section{Ethical Considerations:}

The studied subjects were informed that their participation in the study was completely voluntary and there was no harm if they are not participating in the study. Oral consent was obtained from the head nurses and staff nurses participating in the study after explaining the nature, purposes, and benefits of the study. Each assessment sheet was coded and participants' names were not appearing on the sheets for anonymity and confidentiality.

\section{Statistical Design:}

Data entry and statistical analysis were done using SPSS version 20.0 (Statistical Soft Ware Package). Data were presented using descriptive statistics in the form of frequency, mean, standard deviation, and range. Pearson correlation analysis was used for the assessment of the inter-relationships among quantitative variables. Statistical significance was considered at $\mathrm{p}$-value $\leq 0.05$. 
Minia Scientific Nursing Journal (Print - ISSN 2537-012X) (Online - ISSN 2785-9797) Vol. (9) No. (1) June 2021

\section{Results:}

Table (1): Percentage distribution of personal characteristics of the studied nursing staff at Assuit University Hospital $(\mathrm{N}=\mathbf{2 1 9})$.

\begin{tabular}{|c|c|c|}
\hline Personal characteristics & No. & $\%$ \\
\hline \multicolumn{3}{|l|}{ Age: (years) } \\
\hline$<30$ & 55 & 25.1 \\
\hline $30-40$ & 93 & 42.5 \\
\hline$>40$ & 71 & 32.4 \\
\hline Mean \pm SD & \multicolumn{2}{|l|}{$36.06 \pm 8.88$} \\
\hline \multicolumn{3}{|l|}{ Occupation: } \\
\hline Staff nurse & 202 & 92.2 \\
\hline Head nurse & 17 & 7.8 \\
\hline \multicolumn{3}{|l|}{ Educational qualification: } \\
\hline Bachelor Degree of Nursing & 16 & 7.3 \\
\hline Technical Institute of Nursing & 35 & 16.0 \\
\hline Secondary school of Nursing Diploma & 138 & 76.7 \\
\hline \multicolumn{3}{|l|}{ Years of experience: } \\
\hline$<10$ & 42 & 19.2 \\
\hline $10-20$ & 95 & 43.4 \\
\hline$>20$ & 82 & 37.4 \\
\hline Mean \pm SD & \multicolumn{2}{|l|}{$17.11 \pm 8.69$} \\
\hline \multicolumn{3}{|l|}{ Attended training courses : } \\
\hline Yes & 111 & 50.7 \\
\hline No & 108 & 49.3 \\
\hline \multicolumn{3}{|l|}{ Training courses: $\neq$} \\
\hline Infection control & 90 & 81.0 \\
\hline CPR & 6 & 5.4 \\
\hline Quality & 20 & 18.0 \\
\hline Occupational safety and health & 4 & 3.6 \\
\hline
\end{tabular}

$\neq$ More than one answer

Table (1): Indicates that the age of the studied nursing staff one-quarter of them $(25.1 \%)$ age less than 30 years old, less than half of them (42.5\%) age from 30 to 40 years old respectively, and more than one-third of them (32.4\%) age more than 30 years old with mean age $(36.06 \pm 8.88)$. The majority of them $(92.0 \%)$ are a staff nurse. Educational qualification more than three quarters $(76.7 \%)$ were a secondary school of nursing, while less than quarter of them $(16.0 \%)$ have a technical institute of nursing, and the lowest percentage of them (7.3\%) Faculty of Nursing from the table for years of experience less than half of them (43.4\%) have twenty years of experience, while more than one-third of them $(37.4 \%)$ have less than twenty years of experience, and less than quarter of them $(19.2 \%)$ had more than years of experience respectively with a mean $(17.11 \pm 8.69)$, more than half of them attended training courses $(50.7 \%)$, which classified according to training courses about $(81.1 \%)$ have infection control training courses, and less than a quarter of them $(18.0 \%)$ have training on quality courses.

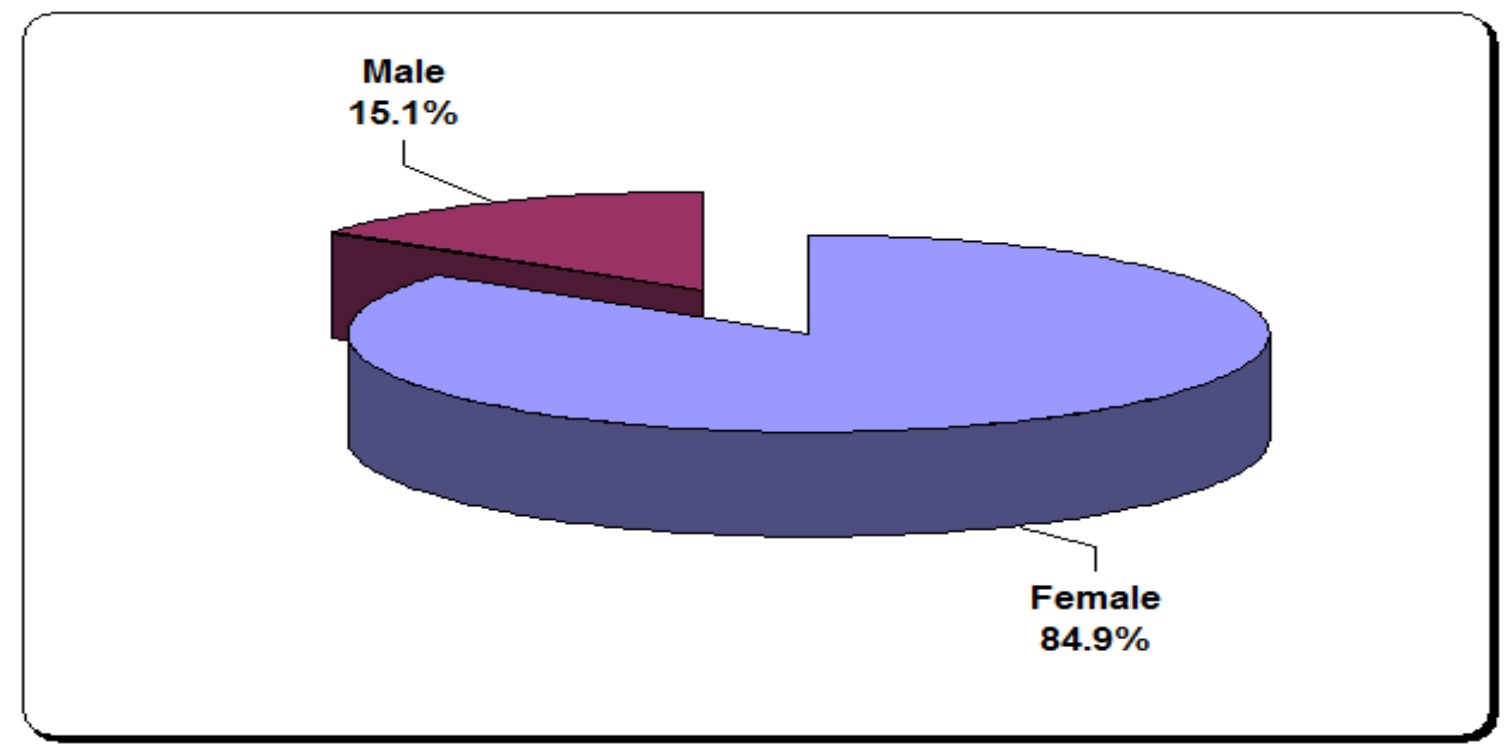

Figure (1): Percentage distribution of gender of the studied nursing staff at Assuit University Hospital (N=219).

Fig (1): shows that the majority (84.9\%) of studied nursing staff are females. 


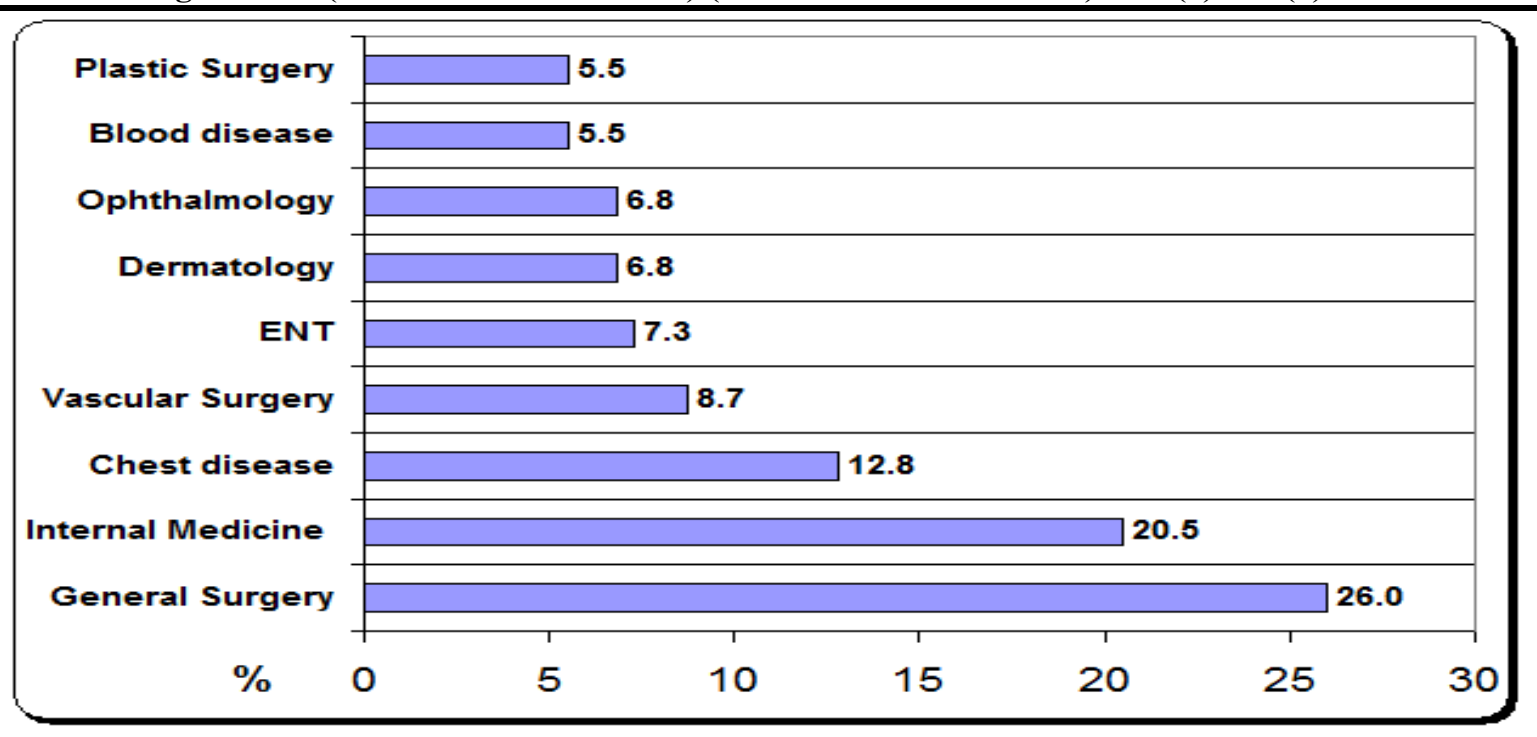

Figure (2): Percentage distribution of work place among studied nursing staff at Assuit University Hospital (N=219).

Fig(2): Illustrates that about the place of work more than a quarter of the studied nursing staff in General Surgery ( 26.0\%), while less than quarter of the studied nursing staff in Internal Medicine (20.5\%), and the lowest percentage (5.5\%) working in Plastic Surgery and Blood Disease respectively.

Table (2): Percentage distribution of challenges of applying quality management as reported by studied nursing staff at Assuit University Hospital ( $\mathrm{N}=\mathbf{2 1 9})$.

\begin{tabular}{|c|c|c|c|c|c|c|c|c|c|c|}
\hline \multirow[t]{2}{*}{ Challenges of total quality management } & \multicolumn{2}{|c|}{$\begin{array}{l}\text { Strongly } \\
\text { agree }\end{array}$} & \multicolumn{2}{|c|}{ Agree } & \multicolumn{2}{|c|}{ Neutral } & \multicolumn{2}{|c|}{ disagree } & \multicolumn{2}{|c|}{$\begin{array}{l}\text { Strongly } \\
\text { disagree }\end{array}$} \\
\hline & No. & $\%$ & No. & $\%$ & No. & $\%$ & No. & $\%$ & No. & $\%$ \\
\hline Lack of qualified personnel to implement TQM & 68 & 31.1 & 85 & 38.8 & 44 & 20.1 & 20 & 9.1 & 2 & 0.9 \\
\hline $\begin{array}{l}\text { No advertising for total quality system in the health } \\
\text { director }\end{array}$ & 65 & 29.7 & 94 & 42.9 & 42 & 19.2 & 15 & 6.8 & 3 & 1.4 \\
\hline No available resources to apply TQM & 69 & 31.5 & 95 & 43.4 & 36 & 16.4 & 16 & 7.3 & 3 & 1.4 \\
\hline No plans for quality in the hospital & 58 & 26.5 & 82 & 37.4 & 63 & 28.8 & 10 & 4.6 & 6 & 2.7 \\
\hline Lack of competition between departments in the hospital & 59 & 26.9 & 89 & 40.6 & 52 & 23.7 & 14 & 6.4 & 5 & 2.3 \\
\hline $\begin{array}{l}\text { Some employees believe that the application of TQM is } \\
\text { only for oversight }\end{array}$ & 58 & 26.5 & 79 & 36.1 & 60 & 27.4 & 18 & 8.2 & 4 & 1.8 \\
\hline Lake of training of nursing on quality & 57 & 26.0 & 87 & 39.7 & 42 & 19.2 & 24 & 11.0 & 9 & 4.1 \\
\hline $\begin{array}{|llll|}\text { Lake of adequate encouragement } & \text { from senior } \\
\text { management in the application of TQM } & & \\
\end{array}$ & 55 & 25.1 & 93 & 42.5 & 44 & 20.1 & 16 & 7.3 & 11 & 5.0 \\
\hline $\begin{array}{l}\text { Employees consider TQM as a service of luxury and well- } \\
\text { being }\end{array}$ & 53 & 24.2 & 85 & 38.8 & 54 & 24.7 & 21 & 9.6 & 6 & 2.7 \\
\hline $\begin{array}{l}\text { Existing administrative structure does not allow the } \\
\text { application of TQM }\end{array}$ & 50 & 22.8 & 80 & 36.5 & 61 & 27.9 & 22 & 10.0 & 6 & 2.7 \\
\hline $\begin{array}{l}\text { Senior management resistance the application of TQM in } \\
\text { the hospital }\end{array}$ & 53 & 24.2 & 80 & 36.5 & 63 & 28.8 & 17 & 7.8 & 6 & 2.7 \\
\hline \begin{tabular}{|l} 
Weak administrative communication between senior \\
management and service providers
\end{tabular} & 56 & 25.6 & 90 & 41.1 & 46 & 21.0 & 15 & 6.8 & 12 & 5.5 \\
\hline Resistance of some workers to change in hospital & 85 & 38.8 & 82 & 37.4 & 42 & 19.2 & 8 & 3.7 & 2 & 0.9 \\
\hline Central decision-making in the hospital & 58 & 26.5 & 101 & 46.1 & 42 & 19.2 & 16 & 7.3 & 2 & 0.9 \\
\hline Hospital requirements activities with absolute clarity & 66 & 30.1 & 81 & 37.0 & 52 & 23.7 & 14 & 6.4 & 6 & 2.7 \\
\hline $\begin{array}{l}\text { Prevents stagnation of the policies and procedure of the } \\
\text { application of TQM in hospital }\end{array}$ & 47 & 21.5 & 91 & 41.6 & 61 & 27.9 & 17 & 7.8 & 3 & 1.4 \\
\hline The inability of training programs to carry out their work & 49 & 22.4 & 93 & 42.5 & 55 & 25.1 & 21 & 9.6 & 1 & 0.5 \\
\hline Lack of an effective incentive system & 59 & 26.9 & 93 & 42.5 & 50 & 22.8 & 14 & 6.4 & 3 & 1.4 \\
\hline Lack of good and up-to-date information systems & 60 & 27.4 & 92 & 42.0 & 50 & 22.8 & 15 & 6.8 & 2 & 0.9 \\
\hline $\begin{array}{l}\text { Lack of focus on encouraging individual initiatives of } \\
\text { creativity and innovation }\end{array}$ & 62 & 28.3 & 90 & 41.1 & 49 & 22.4 & 15 & 6.8 & 3 & 1.4 \\
\hline $\begin{array}{l}\text { Resistance of health care providers to patients' } \\
\text { involvement in expressing their views on health care } \\
\text { provided }\end{array}$ & 58 & 26.5 & 83 & 37.9 & 63 & 28.8 & 12 & 5.5 & 3 & 1.4 \\
\hline $\begin{array}{l}\text { Lack of a sound policy to develop training programs } \\
\text { based on actual needs }\end{array}$ & 58 & 26.5 & 85 & 38.8 & 54 & 24.7 & 15 & 6.8 & 7 & 3.2 \\
\hline $\begin{array}{l}\text { Do not keep pace with scientific and technical changes by } \\
\text { healthcare providers }\end{array}$ & 55 & 25.1 & 87 & 39.7 & 61 & 27.9 & 14 & 6.4 & 2 & 0.9 \\
\hline \begin{tabular}{|l}
$\begin{array}{l}\text { Lake to delegate responsibilities and lake of tasks } \\
\text { distribution }\end{array}$ \\
\end{tabular} & 60 & 27.4 & 91 & 41.6 & 34 & 15.5 & 29 & 13.2 & 5 & 2.3 \\
\hline Lack of focus on satisfaction of hospital staff & 75 & 34.2 & 83 & 37.9 & 33 & 15.1 & 26 & 11.9 & 2 & 0.9 \\
\hline Lack of focus on patient satisfaction & 63 & 28.8 & 90 & 41.1 & 33 & 15.1 & 32 & 14.6 & 1 & 0.5 \\
\hline
\end{tabular}


Table (2): Shows that less than half of studied nursing staff agrees about the items (central decision-making in the hospital; no advertising for the total quality system in the health director; lack of adequate encouragement from senior management in the application of TQM; lack of an effective incentive system; the inability of training programs to carry out their work; lack of good and up-to-date information systems; prevents stagnation of the policies and procedure of the application of TQM in hospital; lake to delegate responsibilities and lake of tasks distribution; and lack of focus on patient satisfaction) ranged from (46.1\% to $41.1 \%)$. While more than one-third of them strongly agree for the items (resistance of some workers to change in hospital; no available resources to apply TQM; no advertising for the total quality system in the health director; and lack of qualified personnel to implement TQM) ranged from $(38.8 \%$ to $31.1 \%)$ respectively.

Table (3): Percentage distribution of open ended question about other challenges for the application of total quality management as reported by studied nursing staff at Assuit University Hospital ( $\mathrm{N}=\mathbf{2 1 9})$.

\begin{tabular}{|l|l|l|}
\hline Open ended question about other challenges for the application of total quality management & No. & $\%$ \\
& & \\
\hline -There are no training courses about quality for nursing personnel in different departments. & $\mathbf{1 6}$ & $\mathbf{7 . 3}$ \\
\hline -There is no patient examination room in different departments. & $\mathbf{4}$ & $\mathbf{1 . 8}$ \\
\hline -Unavailable meetings with nurses to discuss work obstacles and nursing problems. & 3 & 0.5 \\
\hline -Increased number of patients in different departments. & 2 & 0.9 \\
\hline
\end{tabular}

Table (3): Clarifies that other challenges facing the studied nursing staff for the application of total quality management for the items (there are no training courses about quality for nursing personnel in different departments $(7.3 \%)$, there is no patient examination room in different departments $(1.8 \%)$ respectively.

Table (4): Relation between total quality management challenges with personal characteristics as reported by studied nursing staff at Assuit University Hospital(N=219).

\begin{tabular}{|c|c|c|c|}
\hline \multirow[t]{2}{*}{ Personal characteristics } & $\begin{array}{ll}\begin{array}{l}\text { Quality } \\
\text { challenges }\end{array} & \text { management }\end{array}$ & \multirow[t]{2}{*}{ T-value } & \multirow[t]{2}{*}{ P-value } \\
\hline & Mean \pm SD & & \\
\hline \multicolumn{4}{|l|}{ Age: (years) } \\
\hline$<30$ & $102.00 \pm 13.48$ & \multirow[t]{3}{*}{0.994} & \multirow[t]{3}{*}{0.372} \\
\hline $30-40$ & $99.38 \pm 18.54$ & & \\
\hline$>40$ & $97.70 \pm 17.30$ & & \\
\hline \multicolumn{4}{|l|}{ Gender: } \\
\hline Female & $100.01 \pm 16.73$ & \multirow[t]{2}{*}{0.991} & \multirow[t]{2}{*}{0.291} \\
\hline Male & $96.61 \pm 18.41$ & & \\
\hline \multicolumn{4}{|l|}{ Occupation: } \\
\hline Staff nurse & $99.49 \pm 16.48$ & \multirow[t]{2}{*}{-0.007} & \multirow[t]{2}{*}{0.993} \\
\hline Head nurse & $99.53 \pm 22.92$ & & \\
\hline \multicolumn{4}{|l|}{ Educational qualification: } \\
\hline Bachelor Degree of Nursing & $102.19 \pm 20.79$ & \multirow[t]{3}{*}{1.170} & \multirow[t]{3}{*}{0.312} \\
\hline Technical Institute of Nursing Diploma & $102.89 \pm 13.48$ & & \\
\hline Secondary school of Nursing & $98.53 \pm 17.24$ & & \\
\hline \multicolumn{4}{|l|}{ Years of experience: } \\
\hline$<10$ & $100.76 \pm 16.36$ & \multirow[t]{3}{*}{2.418} & \multirow[t]{3}{*}{0.092} \\
\hline $10-20$ & $101.71 \pm 16.65$ & & \\
\hline$>20$ & $96.28 \pm 17.41$ & & \\
\hline \multicolumn{2}{|l|}{ Attended training courses : } & \multirow[t]{3}{*}{-0.817} & \multirow[t]{3}{*}{0.415} \\
\hline Yes & $98.57 \pm 17.24$ & & \\
\hline No & $100.44 \pm 16.77$ & & \\
\hline \multicolumn{4}{|l|}{ Work place: } \\
\hline Surgery & $99.85 \pm 16.93$ & \multirow[t]{2}{*}{-0.374} & \multirow[t]{2}{*}{0.708} \\
\hline Medicine & $98.97 \pm 17.18$ & & \\
\hline
\end{tabular}

Table (4): Shows that the highest mean scores are in challenges of total quality management; educational qualification $(102.89 \pm 13.48)$, age $(102.00 \pm 13.48)$, gender $(100.01 \pm 16.73)$, years of experience (101.71 \pm 16.65$)$, attended training courses (100.44 \pm 16.77$)$, workplace $(99.85 \pm 16.93)$, occupation $(99.53 \pm 22.92)$, with no statistically significant differences with personal characteristics.

\section{Discussion}

Total Quality Management is one of the most important changes which have taken place in the field of health care management. Total Quality Management is a comprehensive and applied strategy to achieve administrative development and improve the quality of services to respond to the needs and expectations of the society. The purpose of total quality management is to optimize human powers and improving the quality of patient care through establishing the system in the units. Total quality management is not regarded as the final process of improvement, but everyone should try to achieve it and view improvement as a continuous process. The effectiveness of an organization depends on the extent to which people perform their roles and move towards corporate goals and objectives. (Faloudah, et al., 2015). The current study is to assess nursing staff awareness regarding challenges for applying total quality management at Assuit University Hospital 
The finding of the present study revealed that the majority of the nursing staff was females. This indicates that the female is attracted to nursing so nursing is a feminine profession. This result is in the same line with Maiolo, (2014) who stated that the nursing profession still depends on women rather than men. This result is consistent with Elewa \& Elkattan, (2017) who indicate that less than three-quarters of them were females and more than one-quarter of them were males. This result is incongruent with Alaraki, (2018) who stated that more than three-quarters of them were males, and less than one-quarter of them were females.

The study finding revealed that less than half of the nursing staff was between $30-40$ years old, more than a quarter of the studied nursing staff was graduated from the Secondary School of Nursing and the majority of them were staff nurses. On the other hand, less than half of the studied nursing staff had experienced between $10<20$ years, and less than half of nursing staff did not have any training courses. This result is congruent with Elewa \& Elkattan, (2017) who show that the mean age of the nurses was more than a quarter of them and less than half of them were in the age group of 30 $-<40$ years. Less than three-quarters of them had nursing diplomas, less than half of them had from $1-<5$ years of experience in hematology units, while less than three-quarters of them didn't receive any training courses. This result is incongruent with Mohamed, (2016) who stated that the majority of the respondents had attained a Bachelor's degree followed by diplomas then a Master's degree, and finally certificates in various fields. This showed that the respondents had the adequate ability to understand and answer the questions relating to TQM and competitive advantage.

Moreover, the finding of the present study showed that less than half was agreement related to "Central decision making in the hospital" (table, 2). This might be due to the nurses do not understand the effect of central decision-making on organizational performance. This result is incongruent with Shokry, \& Soliman, (2016) who indicate that centralized decision-making and increase bureaucratic level influenced negatively on TQM and academic accreditation standards application (AAS) in the nursing program at Shaqra and Taif Universities. This result is incongruent with Yang, Zhou \& Zhang, (2015) who stated that centralization may help enhance cooperation and commitment, resolve functional disagreements, and promote efficient knowledge sharing within the firm, as well as lead to better innovation performance.

Additionally, the finding of the present study revealed that one-third of the studied nursing staff was in a strong agreement related to " No available resources to apply total quality management " (table, 2). This might be due to the nurses know that the organization must provide the employees with the necessary resources and equipment needed to accomplish their work. This result is inconsistent with Mosadeghrad (2015) who mentioned that a good health care system should make use of the available resources as much as possible to obtain the best value for money thus efficient and added that a strategic quality plan ensures the availability of resources for total quality management implementation. This finding is inconsistent with the study done by Mosadeghrad, (2014) who found that supportive managerial and clinical leadership facilitates the implementation of strategic collaborative quality management (SCQM) in healthcare organizations by providing direction and resources for continuous quality improvement.
Furthermore, the finding of the present study clarified that above one-third of the studied sample was agreement related to "Senior management resistance the application of total quality management in the hospital" (table, 2). This might be due to the nurses not understand that top management stands as the front runner of any institution, organization, company, in which the outcome is a reflection of their capability and commitment. This result is incongruent by Javed, (2015) who stated that top management commitment was the basis of the total quality management implementation process and that it is almost impossible to overstate the influence of the senior management role. Top managements necessary throughout each stage of the process of implementation. Likewise, Tzempelikos, (2015) found that the top management in an organization has to set the direction of any efforts to create a customer orientation; including clear and recognizable quality values, and high expectations of other employees. Top management must ensure that strategies are created, together with the systems and methods required to achieve excellence.

In addition, the finding of the present study revealed that one-third of the studied sample was strongly in agreement related to the "Lack of qualified personnel to implement total quality management " (table, 2). This could be due to a nursing deficit in a number of areas, which has hampered the adoption of overall quality management. This result is incongruent with Mosadeghrad, (2014) who found that lack of employees' and managers' consistent commitment to and involvement in total quality management activities were the most cited barriers to total quality management implementation in healthcare organizations.

Moreover, the finding of the present study illustrated that more than one-third of the studied sample was agreement related to "No plans for quality in the hospital" (table, 2). This might be due to the nurse is unaware of whether or not the hospital has a quality-control plan in place. This result is incongruent with Neis, Pereira \& Maccari, (2017) who mentioned that strategic quality planning is necessary for integrating quality objectives, requirements, and targets into organizational operations and activities.

There are no statistically significant correlations between total quality management challenges for application with personal characteristics (table, 3). This result is consistent with Al-Daibat, \& Al-Daibat, (2016) who found that there is no statistically significant effect $(\alpha \leq 0.05)$ of demographic factors (gender, age, experience, job title) to implements total quality management. This result is in agreement with Tohamy \& Al Raoush, (2015) who found that there is no statistically significant effect $(\alpha \leq 0.05)$ of occupation (job title) on workers' perception towards impalements of total quality management.

The result of the present study revealed that there are no statistically significant differences between quality management challenges with academic qualifications (table, 3). This might be due to that the academic qualification of nurse specialists and nurses does not affect total quality management application. This result is in agreement with Shokry \&Soliman, (2016) who illustrated that educational level didn't significantly affect the nursing educators' perceptions of influences on application of total quality management and academic accreditation standard (AAS) at Shaqra University. This result is consistent with Altahayneh, (2014) who found that academic rank and education level didn't significantly affect the faculty members' 
perceptions of total quality management implementation. This result is inconsistent with Mohamed et al., (2015) who mentioned that significant differences among nursing educators across academic departments regarding their perception of overall institutional quality and its dimensions.

The finding of the present study clarified that there is no statistically significant correlations between quality management challenges with attending training courses (table 3). This might be due to that the nurses did not attend total quality management training courses or programs to know all information about total quality management. This result is incongruent with Madanat, \& Khasawneh, (2017) who found that the implementation of total quality management principles has a significant impact on training and development effectiveness. Continuous improvement accounts for $34.5 \%$, employee engagement $1.5 \%$, and customer focus. The top management commitment variable was not a potent factor in explaining the variation in training and development.

The result of the present study revealed that there is no statistically significant difference between total quality management application challenges with a place of work (table, 3). This might be due to that nurses have the same information about total quality with different departments. This result is incongruent with Korani, (2017) who found that there was a statistically significant difference between the working place of the studied sample and their opinion about the obstacles of applying total quality management.

\section{Conclusions}

According to the result, it found that above onethird of nursing staff agree about all items of challenges for applying total quality management and no statistically significant differences between total quality management application challenges with personal characteristics of the studied nurses at Assuit University Hospital.

\section{Recommendations}

- Conduct an awareness session about total quality management between nurses at Assuit University Hospital.

- Availability of total quality management training or program to all nurses at Assuit University Hospital.

- Appoint a quality assurance coordinator nurse in each department who works to implement quality policies in the departments and acts as a link between the department and the Quality Committee.

- Rewarding the department that follows quality policies.

- Ensure availability of sufficient supplies and equipment.

\section{References:}

(1) Mosadeghrad , A. (2014): Factors Affecting Medical Service Quality. Iranian J Publ Health, 43 (2). Pp.210-220.

(2) Najm, N, Yousif, A \& Al-Ensour, J. (2017): Total Quality Management (TQM), Organizational Characteristics and Competitive Advantage. Journal of Economic \& Financial Studies 5(04):Pp.12-23. DOI:10.18533/jefs.v5i04.293.

(3) Hao, M \& Yazdanifard, R. (2015): How Effective Leadership can Facilitate Change in Organizations through Improvement and Innovation. 15 (9) Version 1.0. Global Journals Inc. (USA). Pp.15 .
(4) Wamuyu, G. (2015): Total Quality Management in Kenya's Healthcare Industry. Research Project Submitted in Partial Fulfilment of the Requirements for the Award of Master of Business Administration, School of Business. University of Nairobi. D61/79349/2012.

(5) Elewa, A, Elkattan,B, (2017): "Effect of an Educational Program on Improving Quality of Nursing Care of Patients with Thalassemia Major as Regards Blood Transfusion.” American Journal of Nursing Research, 5 (1).Pp. 13-21.

(6) Korani, M. (2017): Assessment Nursing Staff Opinion of the Requirement and Obstacles to Adopt TQM in the Selected Hospitals at Fayoum Governorate, Faculty of Nursing, Cairo University. Unpublished Master Degree Thesis.

(7) Maiolo, A, (2014): Nursing still seen as women's work. Campus Review. Retrieved from:http://www.campusreview.com.au/blog/2014/02/ nursingstill-seen-as-womens-work/ (Accessed3/02/2014).

(8) Faloudah, A, Qasim, S \& Bahumayd, M, (2015): Total Quality Management in Healthcare, International Journal of Computer Applications (0975 - 8887) 120 (12). Pp. 22-24. DOI: $10.5120 / 21280-4160$

(9) Alaraki, M. (2018): Assessing the Organizational Characteristics Influencing Quality Improvement Implementation in Saudi hospitals. Nurse Care Open Access J. 5 (4):Pp.196-203.DOI: 10.15406/ncoaj.2018.05.00147.

(10) Mohamed, H. (2016): Effect of Total Quality Management Practices on Competitive Advantage of Transport and Logistics Firms in Mombasa County, Kenya. A research Project. D61/71494/2014.

(11) Shokry,W, Soliman,H, (2016): Study of Influences on Total Quality Management and Academic Accreditation Standards. Application in Nursing Program at Saudi Universities, IOSR Journal of Nursing and Health Science, 5(5) Ver. VIII, Pp. 5-13.

(12) Yang, Z, Zhou,X \& Zhang,P. (2015): Centralization and Innovation Performance in an Emerging Economy: Testing the Moderating Effects. Asia Pac J Manag 32: Pp. 415-442. DOI 10.1007/s10490-014-9394-8

(13) Mosadeghrad, A. (2015): Developing and Validating A total Quality Management Model for Healthcare Organizations, 27 (5). Pp. $544-564$.

(14) 14- Mosadeghrad, A. (2014): Why Total Quality Management Programs Fail? A pathology Approach, the TQM Journal, 26 (2). Pp. 160-187. DOI 10.1108/TQM-12-2010-0041.

(15) Javed,S. (2015): Impact of Top Management Commitment on Quality Management International Journal of Scientific and Research Publications, 5 (8). Pp. 314-318.

(16) Tzempelikos, N. (2015): "Top Management Commitment and Involvement and their Link to Key Account Management Effectiveness", Journal of Business \& Industrial Marketing, 30 (1). Pp.32-44.

(17) Neis, D, Pereira, M\& Maccari,E. (2017): Strategic Planning Process and Organizational Structure: Impacts, Confluence and Similarities. BBR, Braz. Bus. Rev, 14 (05). Pp. 472-479.

(18) Al-Daibat, B \& Al-Daibat, M, (2016): Impediments of Total Quality Management Application at Higher Education Institutions, European Journal of Business and Management, 8 (36).Pp 44-55.

(19) El-Tohamy, A, Al Raoush, A. (2015): The Impact of Applying Total Quality Management Principles on The Overall Hospital Effectiveness: an Empirical Study on The HCAC Accredited Governmental Hospitals in Jordan, European Scientific Journal, 11 (10).Pp. 63-76.

(20) Altahayneh, Z. (2014): Implementation of Total Quality Management in Colleges of Physical Education in Jordan International Journal of Business and Social Science, 5 (3).Pp.109117.

(21) Mohamed, R, Abou Hashish, E \& El-Bialy G. (2015): Academic Nursing Educators and Students' Perception of Institutional Quality. Journal of Nursing Education and Practice, 5(12).Pp. 111121.

(22) Madanat, H \& Khasawneh, A. (2017): Impact of Total Quality Management Implementation on Effectiveness of Human Resource Management in the Jordanian Banking Sector from Employees' Perspective, 16 (1).Pp. 114-147. 